NBER WORKING PAPER SERIES

\title{
THE UNDERREACTION HYPOTHESIS \\ AND THE NEW ISSUE PUZZLE: \\ EVIDENCE FROM JAPAN
}

\author{
Jun-Koo Kang \\ Yong-Cheol Kim \\ René M. Stulz
}

Working Paper 5819

\section{NATIONAL BUREAU OF ECONOMIC RESEARCH 1050 Massachusetts Avenue \\ Cambridge, MA 02138 \\ November 1996}

We are grateful to Chris Géczy, John Griffin, Rohan Williamson, and participants at a seminar at Ohio State University for useful comments. This paper is part of NBER's research programs in Asset Pricing and Corporate Finance. Any opinions expressed are those of the authors and not those of the National Bureau of Economic Research.

(C) 1996 by Jun-Koo Kang, Yong-Cheol Kim and René M. Stulz. All rights reserved. Short sections of text, not to exceed two paragraphs, may be quoted without explicit permission provided that full credit, including $\mathbb{C}$ notice, is given to the source. 
THE UNDERREACTION HYPOTHESIS

AND THE NEW ISSUE PUZZLE:

EVIDENCE FROM JAPAN

Jun-Koo Kang, Yong-Cheol Kim and René M. Stulz

NBER Working Paper 5819

November 1996

Asset Pricing, Corporate Finance

\section{ABSTRACT}

This paper investigates the long-term performance of Japanese firms issuing convertible debt or equity. We find that these firms perform poorly even though the stock-price reaction to convertible debt and equity issue announcements is not significantly negative for Japanese firms and Japanese firms do not issue equity or convertible debt following strong positive abnormal returns. Whereas in the U.S. underperformance appears to be concentrated in the smaller firms and in the firms with a high market-to-book ratio, this is not the case in Japan. The underperformance of Japanese issuing firms cannot be understood in terms of the underreaction hypothesis that some have advanced as an explanation for the poor returns of U.S. issuing firms.

Jun-Koo Kang

College of Business Administration

Korea University

1, Anam-Dong, Sungbuk-Gu

Seoul 136-701

KOREA

René M. Stulz

Harvard Business School

Morgan 381

Harvard University

Soldiers Field Road

Boston, MA 02163

and NBER

rstulz@hbs.edu
Yong-Cheol Kim

Department of Finance

Clemson University

314 Sirriew

Clemson, SC 29634-1301 


\section{Section 1. Introduction.}

Loughran and Ritter (1995) and Spiess and Affleck-Graves (1995) show that seasoned equity issues in the U.S. are followed by abnormally low stock returns. These results seem to hold irrespective of the benchmark used. However, as emphasized by Brav, Géczy and Gompers (1995), the underperformance is much more noticeable for small firms and may well not exist for large firms. At this point, there is no generally accepted explanation for these findings.

Existing studies show that the magnitude of the underperformance is sensitive to the benchmark used to estimate excess returns. In particular, the use of the Fama and French (1993) three-factor model reduces the magnitude of the abnormal returns. It is therefore possible that existing asset pricing models do not take into account a risk factor that is priced in financial markets and on which equity issuing firms load more than other

firms. However, the magnitude of the abnormal returns to be explained seems large. In particular, one would have to find a risk factor that explains why, on average, the returns of firms issuing equity for the first time are lower than the risk-free rate.

There is considerable cross-sectional variation in long-term cumulative returns and the distribution of these returns is not normal. These facts raise delicate issues as to how one should estimate expected returns and how one should evaluate their statistical significance. Kothari and Warner (1996) emphasize the existence of an upward bias in test statistics. Such a bias makes the puzzle of negative abnormal returns for equity-issuing firms worse. However, Barber and Lyons $(1996 a, b)$ find evidence of a downward bias in test statistics, making the precise nature of the biases in existing studies a difficult issue 
to resolve since it appears to depend on the sample period as well as other sample characteristics.

As emphasized by Myers and Majluf (1984) and others, an equity issue provides information to investors that management does not believe that the firm's equity is undervalued by the market. Event study evidence shows that investors react negatively to the announcement of an equity issue. If markets are efficient, one would expect all the information produced by management's decision to issue equity to be immediately incorporated in firm value, so that shareholders of firms issuing equity earn no abnormal returns on average after management's decision to issue equity has become public knowledge. Loughran and Ritter (1995) and others have argued that a possible explanation for the underperformance of equity-issuing firms is that investors underreact to the adverse news of an equity issue. If managers exploit a window of opportunity caused by an overvaluation of the firm, then outsiders do not understand how much the firm is overvalued and learn about the extent of the overvaluation only over time. Chan, Ikenberry and Lakonishok (1995) show that firms buying back equity outperform the market over several years. Since empirical evidence shows that an equity repurchase is good news, the underreaction hypothesis would predict these firms' strong performance. It is, however, difficult to believe that it would take that long for investors to figure things out.

In this paper, we investigate the long-term performance of Japanese securityissuing firms. This evidence is interesting in and of itself because of the importance of the Japanese market, but investigating long-term retums in Japan can also help us understand 
better long-term returns in the U.S. If long-term returns can be explained by investor underreaction alone, one would not expect firms issuing convertible debt and equity in Japan to significantly underperform. This is because the stock price reaction to the announcement of equity and convertible debt issues is nonnegative in Japan in contrast to the U.S. where it is significantly negative. In particular, Kato and Schallheim (1992) and Kang and Stulz (1996) document that there is no significant negative average abnormal return when a Japanese firm announces a public equity issue. As in the U.S., Japanese firms experience a significant positive abnormal return when they issue equity privately. Kang and Stulz (1996) show that Japanese firms issuing convertible debt in Japan experience a significant positive abnormal return, whereas Kang, Kim, Park, and Stulz (1995) report that Japanese firms issuing convertible debt offshore experience insignificant abnormal returns. These results therefore imply that the investor underreaction hypothesis has different implications for security issues by Japanese firms than it does for security issues by U.S. firms. If investors truly underreact, then one would expect the Japanese firms issuing convertible debt domestically and equity privately to outperform comparable firms that do not issue. Furthermore, there would be no reason for firms issuing equity or convertible debt offshore to underperform. In addition, Kang, Kim, Park and Stulz (1995) and Kang and Stulz (1996) show that Japanese firms do not issue equity or convertible debt after having experienced large positive abnormal returns like American firms. Consequently, if the underperformance of issuing firms in the U.S. is another manifestation of the contrarian phenomenon documented by DeBondt and Thaler (1985), it should not occur in Japan. 
Our results show that convertible debt and equity issuing firms in Japan perform less well than firms of similar size that do not issue. Convertible issuing firms underperform for at least three years and equity issuing firms underperform for at least five years. Not only do firms that issue public equity underperform non-issuing firms of similar size but, more surprisingly, the performance of firms issuing equity privately is not different from the performance of firms issuing equity publicly. The magnitude of the underperformance is sensitive to the benchmark used. Barber and Lyons (1996a) recommend use of the matched-firm technique and find that test statistics are not misspecified with this technique. Chan, Hamao and Lakonishok (1991), Kubota and Takehara (1995) and Jagannathan, Kubota and Takehara (1995) provide evidence that both size and market-to-book are important in understanding cross-sectional variation in expected returns for Japan. Underperformance exists whether we use matching firms of similar size, similar market-tobook, or similar size and similar market-to-book.

Brav, Géczy and Gompers (1995) find that in the U.S. firms with a high market-tobook ratio underperform more than firms with a low market-to-book ratio and that large firms underperform less than small firms. Using size and market-to-book matched returns and sorting issuing firms into size quartiles, we find no evidence that underperformance is more prevalent for small firms in Japan. In multivariate regressions, we find that neither market-to-book nor size are useful in explaining the cross-sectional variation in underperformance.

The paper proceeds as follows. In section 2, we present our data and our procedures to compute returns and excess returns. In section 3 , we show excess returns 
relative to the Topix index and explain how these excess returns are heavily correlated with issuing firm size. In section 4, we adopt the matching firm method and show that this method cannot explain the underperformance. We document that the underperformance in Japan is more consistent across firm sizes and market-to-book ratios than it is in the U.S. and is inconsistent with the underreaction hypothesis. Section 5 concludes.

\section{Section 2. The data.}

We obtain the list of firms issuing equity and convertible debt from the Tokyo Stock Exchange Annual Securities Statistics from 1980 to 1988 . We only consider firms for which data is available on the Pacific Basin Capital Market Research Center files for Japan. We then also impose the following criteria on our sample of issuing firms:

1. The offerings by utility and finance firms are excluded (industry codes 501,511 , 512,513 , and 801 ). This criterion makes our sample comparable to the samples used for U.S. studies.

2. The offering firm must be listed on the Tokyo Stock Exchange at least one month before the issue is offered. This insures that the issue is not an initial public offering and that we know the market value of the firm before the issue.

The resulting sample comprises 959 equity offerings and 1,441 convertible bond offerings. Table 1 shows how our sample is distributed among different types of issues. We treat as multiple issues all cases where a firm makes more than one security issue 
during a month. Convertible issues are more frequent in the second half of the sample whereas equity issues are more frequent in the first half of the sample. Note that the sample does not include offshore warrant issues and does not include straight debt issues. During our sample period, there are very few straight debt issues because of issuing restrictions. Warrant bond issues became numerous only after $1986 .^{1}$

In the U.S., large numbers of firms delist from exchanges, so that survivorship biases can change inferences about long-term performance in an important way. The PACAP database has only firms that survived until 1990, and therefore has a survivorship bias. In the U.S., such a bias would be a serious problem. It is not for Japan. During the sample period we use for our tests, namely 1980 to 1993,64 firms delisted from the Tokyo Stock Exchange. This corresponds to about 4 firms per year and the largest number of delistings in our sample is 10 in 1995 l Four of the delisted firms are financial firms that would not have been part of our sample. Further, about one-third of the delisted firms would have been part of our issuing sample. Consequently, the survivorship bias cannot affect our conclusions in a significant way.

\section{Section 3. Abnormal performance.}

Although the capital asset pricing model has limited support in the U.S. or Japan when estimated using a value-weighted portfolio as a proxy for the market portfolio, using

\footnotetext{
${ }^{1}$ See Kang, Kim, Park and Stulz (1995) for a discussion of the evolution of eligibility criteria and of the growth of the offshore warrant bond market.
} 


\section{Table 1}

Sample of issuing firms from 1980 to 1988

The sample includes all the issues of convertible debt and seasoned equity obtained from the Tokyo Stock Exchange new offerings statistics for firms with data available from the PACAP files that are not financial firms and utilities and that meet our sampling criteria.

\begin{tabular}{|c|c|c|c|c|c|c|c|}
\hline \multirow[t]{3}{*}{ Year } & \multicolumn{4}{|c|}{ Convertible debt issues } & \multicolumn{3}{|c|}{ Equity issues } \\
\hline & \multirow{2}{*}{$\begin{array}{l}\text { Domestic } \\
\text { public is- } \\
\text { sues }\end{array}$} & \multicolumn{2}{|l|}{ Offshore } & \multirow{2}{*}{$\begin{array}{l}\text { Multi- } \\
\text { ple is- } \\
\text { sues }\end{array}$} & \multirow{2}{*}{ Private } & \multirow{2}{*}{ Public } & \multirow{2}{*}{ Rights } \\
\hline & & Private & Public & & & & \\
\hline 1980 & 12 & 38 & 17 & 4 & 11 & 156 & \\
\hline 1981 & 34 & 44 & 38 & 4 & 15 & 170 & 5 \\
\hline 1982 & 45 & 54 & 20 & 5 & 10 & 138 & 18 \\
\hline 1983 & 44 & 80 & 10 & 16 & 17 & 45 & 3 \\
\hline 1984 & 76 & 89 & 19 & 23 & 9 & 71 & 4 \\
\hline 1985 & 100 & 50 & 22 & 23 & 16 & 47 & 12 \\
\hline 1986 & 119 & 23 & 2 & 1 & 13 & 43 & 5 \\
\hline 1987 & 196 & 34 & 4 & 3 & 14 & 38 & 4 \\
\hline 1988 & 162 & 75 & 2 & 3 & 17 & 73 & 5 \\
\hline All & 788 & 487 & 134 & 82 & 122 & 781 & 56 \\
\hline
\end{tabular}


such a proxy provides useful insights in the nature of the underperformance of issuing firms. Table 2 shows three-year and five-year excess returns for our various samples using the Topix index as a benchmark. The Topix is a value-weighted index of the stocks in the first section of the Tokyo Stock Exchange. These returns are buy-and-hold excess returns cumulated over three- and five-year periods. The computation method is the same as the one described in Ritter and Loughran (1995) in their study of long-term performance for U.S. equity-issuing firms. The t-statistics are based on the cross-sectional standard deviations assuming excess returns to be independent. ${ }^{2}$ We first consider the three-year excess returns in Panel A. All average excess returns are negative with the exception of private equity issues and rights issues. However, the average excess returns are significantly negative only for domestic convertible issues, private convertible offshore issues and firms for which multiple issues take place in the same month. The average excess return for rights offerings is significantly positive. Except for offshore private convertible issues, multiples issues, and rights offerings, the average excess returns are economically small. The medians are not economically small, however. The median for private equity issues of $-15.21 \%$ is very similar to the median for public equity issues of $17.14 \%$ and the median of domestic convertible issues of $-14.60 \%$. The excess returns for offshore convertible issues are larger than for the other types of issues. When we turn to the five-year excess returns in Panel B, all excess returns are significantly negative except

\footnotetext{
${ }^{2}$ See Barber and Lyons (1996a) for a discussion of why t-statistics based on cross-sectional standard deviations are preferable in such studies.
} 
for private equity issues and rights issues. The average for public convertible issues is only $-9.19 \%$ and the median is $-13.18 \%$. In contrast, the average for public equity issues is $36.66 \%$ and the median is $-45.20 \%$. The dramatic worsening of the performance of the equity issuing firms over the last two years of the five-year period will show up with other benchmarks also. Whereas the average of private equity excess returns is $-10.92 \%$ and insignificant, the median is an economically large $-25.35 \%$.

The results in Table 2 show underperformance of issuing firms in Japan, but this underperformance is much more substantial when we look at medians than when we look at means. It is interesting to compare our results to similarly constructed estimates for the U.S. Kahle (1996) shows that three-year buy-and-hold retums relative to the value-weighted CRSP index of convertible issuing firms in the U.S. is $-16.5 \%$ with a median of $-26.2 \%$. She also shows that the average excess buy-and-hold returns for equity issuing firms where there is no secondary offering is $-12 \%$ with a median of $-17 \%$. It appears therefore that underperformance is less in Japan over the three-year period.

We investigated the existence of possible size biases by computing the excess returns for size quartiles. Focusing on the results for public domestic convertible and equity issues by firms in the smallest quartile of firms issuing a type of security, we find significant positive excess returns of the three-year period for convertible firms and insignificant positive excess returns for the equity issuing firms. In contrast, when we look at the largest firms, we find large negative excess returns for issuing firms irrespective of the type of security issued except for firms with rights offerings (the t-statistics are significant in all cases except offshore public issues $(t=-1.51)$ and public equity issues $(t=-1.54))$. Similar 


\section{Table 2}

Average and median excess returns relative to the Topix index for three-year and five-year periods

The sample includes all the issues of convertible debt and seasoned equity obtained from the Tokyo Stock Exchange new offerings statistics for firms with data available from the PACAP files that are not financial firms or utilities. Excess returns are buy-and-hold returns of issuing firms minus buy-and-hold returns of the Topix index.

\begin{tabular}{|l|l|l|l|l|l|l|}
\hline \multicolumn{3}{|c|}{ Convertible issues } & \multicolumn{3}{c|}{ Equity issues } \\
\hline $\begin{array}{l}\text { Domestic } \\
\text { public } \\
\text { issues }\end{array}$ & \multicolumn{2}{|c|}{ Offshore issues } & $\begin{array}{l}\text { Multiple } \\
\text { issues }\end{array}$ & Private & Public & Rights \\
\cline { 2 - 3 } & Private & Public & & & & \\
\hline
\end{tabular}

Panel A. Three-year period.

\begin{tabular}{|l|r|r|r|r|r|r|r|}
\hline Average & $-4.70 \%$ & -19.13 & -4.87 & -42.92 & 1.25 & -2.09 & 22.91 \\
\hline t-statistic & -1.75 & -4.71 & -0.48 & -5.54 & 0.15 & -0.56 & 2.05 \\
\hline & & & & & & & \\
Median & -14.60 & -23.38 & -31.78 & -54.70 & -15.21 & -17.14 & 10.21 \\
\hline
\end{tabular}

Panel B. Five-year period.

\begin{tabular}{|l|r|r|r|r|r|r|r|}
\hline Average & $-9.19 \%$ & -34.05 & -39.91 & -65.54 & -10.92 & -36.66 & 43.14 \\
\hline t-statistic & -2.68 & -5.11 & -3.14 & -4.83 & -0.98 & -7.14 & 1.29 \\
\hline & & & & & & & \\
Median & -13.40 & -37.92 & -58.37 & -81.21 & -25.35 & -45.20 & 4.08 \\
\hline
\end{tabular}


patterns hold for the five-year excess returns (but the t-statistics for the largest firms are substantially larger). These results make it necessary for us to investigate the use of a benchmark that accounts for possible size effects. The other problem with the use of the Topix is that we roughly have as many issuing firms as there are firms on the Tokyo Stock Exchange. Consequently, looking at index returns, we might be evaluating the performance of issuing firms against themselves. The use of a matching firm approach removes both of these problems. In this case, we match firms against similar firms that have not issued within the recent past.

Section 4. Understanding the cross-sectional variation in long-term performance. In the previous section, we reported that excess returns relative to the Topix exhibit strong size effects. This leads us to investigate size-matched returns to see whether the underperformance is simply due to these effects. For each issuing firm, we choose as the matching firm a firm that has not issued over the recent past and has a market value in the month before the issue that is the closest but higher than the market value of the issuing firm. We have data for security issues since 1980. Matching firms have not issued equity or convertible debt for five years or since 1980 , whichever period is shorter. The lack of a list of issues for the period before 1980 means that we may potentially understate underperformance. However, before 1980, the eligibility conditions for domestic public convertible issues were so stringent that there were almost no such issues. Until 1984, we may have matching firms that issued equity within five years. This may bias our results towards finding less underperformance than there actually is. We will discuss this problem 
more later. When a matching firm issues, we replace it by the firm which initially was the second closest in market value to the issuing firm. U.S. studies have so far focused on firms issuing equity and firms issuing debt. In these studies, convertible-issuing firms were generally not excluded in the matching samples for equity-issuing firms. To the extent that convertible-issuing firms might resemble equity-issuing firms in their long-term performance, including convertible-issuing firms as matching firms may overstate the performance of equity-issuing firms relative to the population of firms that do not issue equity in any form. If a matching firm is delisted, we replace it by the firm with the next lowest market capitalization at the time of issue. The results we reproduce here using matching firms of similar size use the whole sample of issuing firms. We also estimated average and median three-year (five-year) excess returns after eliminating all cases where the three-year excess return exceeds $300 \%(500 \%)$ in absolute value. None of our qualitative conclusions are changed when we consider this trimmed sample.

Table 3 shows that size effects do not explain the underperformance. The evidence of underperformance is much stronger once we use the matching firm approach and use firm size as our criterion for selecting matching firms. For the three-year and five-year period, the average excess retums are significant for all issuing firms except for those with rights offerings. The medians are generally closer to the means than they were in Table 2 as one would expect. Interestingly, over the three-year period, the firms issuing equity publicly underperform the least among all firms that underperform significantly. The firms that issue convertible debt offshore publicly do not underperform significantly, but their underperformance is not significantly different from the underperformance of the firms that 
Table 3

Average and median excess returns for three-year and five-year periods

The sample includes all the issues of convertible debt and seasoned equity obtained from the Tokyo Stock Exchange new offerings statistics for firms with data available from the PACAP files that are not financial firms or utilities. Excess returns are buy-and-hold returns of issuing firms minus buy-and-hold retums of a firm with similar equity capitalization.

\begin{tabular}{|l|l|l|l|l|l|l|}
\hline \multicolumn{3}{|c|}{ Convertible issues } & \multicolumn{3}{c|}{ Equity issues } \\
\hline $\begin{array}{l}\text { Domestic } \\
\text { public } \\
\text { issues }\end{array}$ & Offshore issues & $\begin{array}{l}\text { Multiple } \\
\text { issues }\end{array}$ & Private & Public & Rights \\
\cline { 2 - 4 } & Private & Public & & & & \\
\hline
\end{tabular}

Panel A. Three-year period.

\begin{tabular}{|l|r|r|r|r|r|r|r|}
\hline Average & $-33.69 \%$ & -31.52 & -17.32 & -58.59 & -56.89 & -22.97 & -11.99 \\
\hline t-statistic & -6.10 & -4.89 & -1.29 & -3.54 & -3.09 & -4.24 & -0.54 \\
\hline & & & & & & & \\
Median & -19.14 & -34.04 & -28.70 & -45.76 & -17.53 & -19.46 & 1.86 \\
\hline
\end{tabular}

Panel B. Five-year period.

\begin{tabular}{|l|r|r|r|r|r|r|r|}
\hline Average & $-51.77 \%$ & -93.51 & -99.89 & -150.30 & -103.10 & -90.12 & 0.26 \\
\hline t-statistic & -5.61 & -7.16 & -4.53 & -4.65 & -3.71 & -9.16 & 0.01 \\
\hline & & & & & & & \\
Median & -12.36 & -70.93 & -106.90 & -125.30 & -51.90 & -65.34 & -9.81 \\
\hline
\end{tabular}


underperform significantly. For all the issuing firms that underperform, the underperformance is economically significant. Since firms issuing offshore are generally larger and better known firms, the substantial five-year underperformance of firms issuing convertible debt offshore hints at a difference between Japan and the U.S., namely that underperformance in Japan is not concentrated in the smaller, younger firms. We will confirm this later more directly.

The underperformance of firms issuing equity privately is rather striking. Both for the three-year and the five-year periods, the mean underperformance of firms issuing equity privately is worse than the mean underperformance of firms issuing equity publicly. These differences are not statistically significant, but at the very least these results do not support the underreaction hypothesis. This hypothesis suggests that firms issuing equity privately should experience positive excess returns since there is a large positive abnormal return associated with private equity issues.

Table 1 shows that there is substantial variation over time in the frequency of issues. This raises the question of whether the underperformance we document is concentrated in few years. We computed the three- and five-year average excess return for each year's cohort of issuing firms. Table 4 shows the results for the five-year average excess return per cohort year. For domestic issues of convertible debt, there are four significant negative average excess retums, in 1983,1984, 1985, and 1986, one return with a t-statistic of -1.64 in 1981 , and one significant positive excess return in 1988. If we focus on the three-year average excess returns instead, six years are significantly negative and no year is significantly positive. It does not appear, therefore, that underperformance is concentrated 


\section{Table 4}

Five-year average excess returns for each cohort year from 1980 to 1988 The sample includes all the issues of convertible debt and seasoned equity obtained from the Tokyo Stock Exchange new offerings statistics for firms with data available from the PACAP files that are not financial firms and utilities. Excess returns are buyand-hold returns of issuing firms minus buy-and-hold returns of size-matched firms. tstatistics are in parentheses.

\begin{tabular}{|c|c|c|c|c|c|c|c|}
\hline \multirow[t]{3}{*}{ Year } & \multicolumn{4}{|c|}{ Convertible debt issues } & \multicolumn{3}{|c|}{ Equity issues } \\
\hline & \multirow{2}{*}{$\begin{array}{l}\text { Domes- } \\
\text { tic pub- } \\
\text { lic }\end{array}$} & \multicolumn{2}{|l|}{ Offshore } & \multirow{2}{*}{$\begin{array}{l}\text { Multi- } \\
\text { ple is- } \\
\text { sues }\end{array}$} & \multirow[t]{2}{*}{ Private } & \multirow[t]{2}{*}{ Public } & \multirow[t]{2}{*}{ Rights } \\
\hline & & Private & Public & & & & \\
\hline 1980 & $\begin{array}{r}-41.52 \\
(-1.37)\end{array}$ & $\begin{array}{l}10.35 \\
(0.30)\end{array}$ & $\begin{array}{l}-50.63 \\
(-1.58)\end{array}$ & $\begin{array}{l}-18.95 \\
(-0.40)\end{array}$ & $\begin{array}{r}-127.2 \\
(-2.17)\end{array}$ & $\begin{array}{l}-27.30 \\
(-1.89)\end{array}$ & \\
\hline 1981 & $\begin{array}{r}-3.07 \\
(-0.10) \\
\end{array}$ & $\begin{array}{l}-86.11 \\
(-2.67) \\
\end{array}$ & $\begin{array}{r}-112.5 \\
(-2.58)\end{array}$ & $\begin{array}{r}-7.53 \\
(-0.22) \\
\end{array}$ & $\begin{array}{r}-132.0 \\
(-2.04)\end{array}$ & $\begin{array}{l}-67.14 \\
(-3.71) \\
\end{array}$ & $\begin{array}{r}2.22 \\
(0.03) \\
\end{array}$ \\
\hline 1982 & $\begin{array}{l}-65.75 \\
(-1.64)\end{array}$ & $\begin{array}{r}-183.30 \\
(-4.15)\end{array}$ & $\begin{array}{l}-100.1 \\
(-1.54)\end{array}$ & $\begin{array}{c}-76.16 \\
(-0.70)\end{array}$ & $\begin{array}{l}-49.44 \\
(-0.44)\end{array}$ & $\begin{array}{r}-141.3 \\
(-4.78)\end{array}$ & $\begin{array}{l}19.98 \\
(0.19)\end{array}$ \\
\hline 1983 & $\begin{array}{r}-144.00 \\
(-3.56)\end{array}$ & $\begin{array}{r}-179.50 \\
(-5.94)\end{array}$ & $\begin{array}{l}-158.4 \\
(-2.37)\end{array}$ & $\begin{array}{l}-234.9 \\
(-4.10)\end{array}$ & $\begin{array}{l}-225.7 \\
(-2.40)\end{array}$ & $\begin{array}{l}-189.2 \\
(-3.93)\end{array}$ & $\begin{array}{c}-27.03 \\
(-0.18)\end{array}$ \\
\hline 1984 & $\begin{array}{r}-186.30 \\
(-4.55) \\
\end{array}$ & $\begin{array}{r}-137.60 \\
(-4.05)\end{array}$ & $\begin{array}{c}-176.6 \\
(-2.76)\end{array}$ & $\begin{array}{l}-252.4 \\
(-3.32)\end{array}$ & $\begin{array}{l}-218.4 \\
(-1.59)\end{array}$ & $\begin{array}{l}-227.9 \\
(-7.12)\end{array}$ & $\begin{array}{r}-130.6 \\
(-0.92)\end{array}$ \\
\hline 1985 & $\begin{array}{r}-115.80 \\
(-3.90)\end{array}$ & $\begin{array}{c}-76.00 \\
(-1.78)\end{array}$ & $\begin{array}{l}-42.68 \\
(-0.91)\end{array}$ & $\begin{array}{l}-90.91 \\
(-2.03)\end{array}$ & $\begin{array}{l}-69.69 \\
(-1.13)\end{array}$ & $\begin{array}{c}-183.2 \\
(-4.25)\end{array}$ & $\begin{array}{l}24.53 \\
(0.35)\end{array}$ \\
\hline 1986 & $\begin{array}{c}-49.91 \\
(-3.19)\end{array}$ & $\begin{array}{l}-20.25 \\
(-1.13)\end{array}$ & $\begin{array}{c}-54.05 \\
(-0.38)\end{array}$ & -149.0 & $\begin{array}{l}-85.97 \\
(-1.69)\end{array}$ & $\begin{array}{c}-53.08 \\
(-2.34)\end{array}$ & $\begin{array}{l}21.67 \\
(0.63)\end{array}$ \\
\hline 1987 & $\begin{array}{c}-4.77 \\
(-0.88)\end{array}$ & $\begin{array}{l}-20.18 \\
(-1.27)\end{array}$ & $\begin{array}{c}-9.11 \\
(-0.33)\end{array}$ & $\begin{array}{l}-22.53 \\
(-0.51)\end{array}$ & $\begin{array}{c}-53.79 \\
(-2.31)\end{array}$ & $\begin{array}{c}-10.03 \\
(-0.75)\end{array}$ & $\begin{array}{c}-105.4 \\
(-3.62)\end{array}$ \\
\hline 1988 & $\begin{array}{l}10.98 \\
(3.21)\end{array}$ & $\begin{array}{c}-7.96 \\
(-1.37)\end{array}$ & $\begin{array}{r}-113.10 \\
(-2.39)\end{array}$ & $\begin{array}{c}12.08 \\
(0.37)\end{array}$ & $\begin{array}{c}4.96 \\
(0.32)\end{array}$ & $\begin{array}{l}10.33 \\
(1.18)\end{array}$ & $\begin{array}{c}53.24 \\
(1.50)\end{array}$ \\
\hline
\end{tabular}


in the first half of the sample. Investigating this issue further, we divided the sample into one subperiod from 1980 to 1984 and a second subperiod from 1985 to 1988 . The three-year average excess returns for these two subperiods are significantly worse in the second subperiod for the firms issuing public convertible debt offshore, multiple issues, public equity issues, and rights offerings. They are not significantly different for the other issues. The five-year average excess retums for the second subperiod are significantly higher than those for the first subperiod for the firms that issue convertible debt publicly in Japan or privately offshore and for the firms that issue equity publicly. In all cases except for rights offerings, however, the excess returns are negative in both subperiods. Across the threeyear and five-year excess returns, the only cohort that has a significant positive average excess retum is the 1988 cohort where the average excess return is significantly positive for the five-year period.

Turning to equity issues, private equity issues have significantly negative average excess returns for five sample years and one additional year has a negative t-statistic of 1.56. Public equity issues have significant negative excess returns for seven years and no year has a positive significant average excess return. When we look at the three-year excess retums for equity issuing firms, five years have significant negative excess returns and the first sample year has a significant positive abnormal return. In contrast, only one year has a significant negative excess retum for rights issues when we look at the five-year period or the three-year period.

The underperformance documented using the size matching firm approach is not due to a small number of years in the sample period. The question that remains in 
evaluating the economic significance of the results is whether this underperformance is concentrated among the smaller firms. To investigate this, Table 5 splits the sample into size quartiles and shows the results for the five-year period. We find there no evidence that underperformance is concentrated among the smallest firms. For firms issuing equity publicly, size seems irrelevant. For firms issuing convertible debt, underperformance worsens as firm size increases. The one case where undeperformance is noticeably worse for the smallest firms is for private equity issues where the smallest quartile has especially poor performance. On balance, therefore, no case can be made that underperformance is concentrated among the smaller firms in Japan.

There is now much evidence for the U.S. and Japan that stock retums decrease as market-to-book increases. In the U.S., firms that issue equity tend to have high market-tobook ratios, which by itself could explain some underperformance. The problem with the market-to-book effect in this setting is that the evaluation of a finding that underperformance increases with market-to-book is strongly dependent on whether one believes that market-to-book proxies for a risk factor or not. Suppose that one believes that somehow the Fama and French (1994) three-factor model is a good proxy for an intertemporal capital asset pricing model and that market-to-book is highly correlated with unknown priced state variables. In this case, if controlling for market-to-book eliminates the underperformance of issuing firms, one has shown that there is no underperformance when the appropriate asset pricing model is used.

If, on the other hand, one does not believe that the Fama and French (1994) HML factor corresponding to the retum of low market-to-book stocks minus the return of high 


\section{Table 5}

Average excess returns for five-year periods by size quartiles

The sample includes all the issues of convertible debt and seasoned equity obtained from the Tokyo Stock Exchange new offerings statistics for firms with data available from the PACAP files that are not financial firms and utilities. Excess returns are buy-and-hold returns of issuing firms minus buy-and-hold returns of size-matched firms. t-statistics are reported in parentheses.

\begin{tabular}{|c|c|c|c|c|c|c|c|}
\hline & \multicolumn{4}{|c|}{ Convertible issues } & \multicolumn{3}{|c|}{ Equity issues } \\
\hline & & \multicolumn{2}{|c|}{ Offshore issues } & \multirow{2}{*}{$\begin{array}{l}\text { Multiple } \\
\text { issues }\end{array}$} & \multirow[t]{2}{*}{ Private } & \multirow[t]{2}{*}{ Public } & \multirow[t]{2}{*}{ Rights } \\
\hline & & Private & Public & & & & \\
\hline $\begin{array}{l}\text { Quartile 1 } \\
\text { (Smallest } \\
\text { firms) }\end{array}$ & $\begin{array}{c}-33.94 \% \\
(-1.80)\end{array}$ & $\begin{array}{l}-65.11 \\
(-2.23)\end{array}$ & $\begin{array}{l}-76.88 \\
(-1.71)\end{array}$ & $\begin{array}{r}-126.2 \\
(-1.30)\end{array}$ & $\begin{array}{c}-144.1 \\
(-1.91)\end{array}$ & $\begin{array}{l}-99.40 \\
(-3.81)\end{array}$ & $\begin{array}{l}90.79 \\
(0.60)\end{array}$ \\
\hline Quartile 2 & $\begin{array}{c}-45.86 \\
(-2.28) \\
\end{array}$ & $\begin{array}{r}-104.1 \\
(-4.36) \\
\end{array}$ & $\begin{array}{c}-200.5 \\
(-4.60) \\
\end{array}$ & $\begin{array}{c}-202.2 \\
(-3.12) \\
\end{array}$ & $\begin{array}{c}-82.56 \\
(-1.73)\end{array}$ & $\begin{array}{c}-65.44 \\
(-3.88)\end{array}$ & $\begin{array}{c}29.37 \\
(0.41)\end{array}$ \\
\hline Quartile 3 & $\begin{array}{r}-72.13 \\
(-3.72) \\
\end{array}$ & $\begin{array}{l}-86.09 \\
(-3.34)\end{array}$ & $\begin{array}{c}-31.05 \\
(-0.63) \\
\end{array}$ & $\begin{array}{r}-111.2 \\
(-2.13) \\
\end{array}$ & $\begin{array}{c}-84.91 \\
(-1.88)\end{array}$ & $\begin{array}{c}-110.8 \\
(-6.87) \\
\end{array}$ & $\begin{array}{c}-64.67 \\
(-1.08)\end{array}$ \\
\hline $\begin{array}{r}\text { Quartile } 4 \\
\text { (Largest } \\
\text { firms) }\end{array}$ & $\begin{array}{c}-56.15 \\
(-3.74)\end{array}$ & $\begin{array}{c}-117.1 \\
(-4.63)\end{array}$ & $\begin{array}{c}-83.08 \\
(-2.21)\end{array}$ & $\begin{array}{c}-157.6 \\
(-3.59)\end{array}$ & $\begin{array}{r}-104.7 \\
(-1.97)\end{array}$ & $\begin{array}{l}-85.51 \\
(-4.81)\end{array}$ & $\begin{array}{c}-38.05 \\
(-0.60)\end{array}$ \\
\hline
\end{tabular}


market-to-book stocks proxies for state variable risk, controlling for market-to-book can still be useful but the results have to be interpreted with caution. Suppose that one were to find that underperformance disappears when one controls for market-to-book. One possible explanation could be that high market-to-book firms underperform because the market is excessively optimistic about these firms. In this case, controlling for market-to-book may indicate that there is no issuing firm puzzle but only a market-to-book puzzle. Yet, in this case, it would still be important to know why some firms that are overvalued issue securities and others do not.

To evaluate the role of market-to-book, we proceed in several different ways. First, we divide the size-matched results into market-to-book quartiles. This gives us Table 6 . This table shows that there is underperformance both for the smallest market-to-book firms and the largest when one looks at the five-year period. For firms that issue public convertible debt, there is no obvious relation between market-to-book and size-matched excess returns. In contrast, for equity-issuing firms, the lowest market-to-book firms have lower underperformance. Yet, underperformance does not disappear when we look at the lowest market-to-book firms.

Table 6 shows that there is little evidence here that underperformance is a marketto-book phenomenon in Japan. To evaluate the robustness of this conclusion, we also constructed excess returns of issuing firms relative to firms matched on size and book-tomarket. To find a matching firm for an issuing firm, we identified all firms with market value of equity from $50 \%$ to $150 \%$ of the issuing firm and all firms with market-to-book from $50 \%$ to $150 \%$ of the issuing firm. We then considered the intersection of these two sets and 


\section{Table 6}

Average excess returns for five-year periods by market-to-book quartiles The sample includes all the issues of convertible debt and seasoned equity obtained from the Tokyo Stock Exchange new offerings statistics for firms with data available from the PACAP files that are not financial firms and utilities. Excess returns are buy-and-hold returns of issuing firms minus buy-and-hold returns of size-matched firms. t-statistics are in parentheses.

\begin{tabular}{|l|l|l|l|l|l|l|l|}
\hline & \multicolumn{3}{|c|}{ Convertible issues } & \multicolumn{3}{c|}{ Equity issues } \\
\cline { 2 - 7 } & $\begin{array}{l}\text { Domestic } \\
\text { public is- } \\
\text { sues }\end{array}$ & \multicolumn{2}{|c|}{ Offshore issues } & $\begin{array}{l}\text { Multiple } \\
\text { issues }\end{array}$ & Private & Public & Rights \\
\cline { 3 - 8 } & & Private & Public & & & \\
Quartile 1 & -34.14 & -53.49 & -94.96 & -101.8 & -85.46 & -67.10 & 84.87 \\
(lowest \\
market-to- \\
book)
\end{tabular}


ranked its members according to how close they are (in absolute value) in size and marketto-book to the issuing firm. We sum the ranks for size and market-to-book and choose the firm that has the lowest as the matching firm. The results are shown in Table 7.

Matching the issuing firm with a firm of similar size and market-to-book seems to have opposite effects on convertible issuing firms and equity issuing firms. The mean and median abnormal performance fall some for equity issuing firms when we look at the threeyear period. In particular, mean excess returns are not significantly negative for firms that issue equity privately. In contrast, the excess returns of convertible issuing firms seem to worsen - except for the firms with multiple issues. For the five-year period, there is no clear pattern - all results that are significant in table 3 are still significant.

These results show that choosing matching firms according to size and market-tobook does not make the underperformance disappear and does not even reduce it systematically across issuing firms. We investigated these returns to see whether abnormal performance is concentrated among small firms or firms with high market-to-book. Although we do not report these results, the evidence is that there is little consistency across types of issue for the five-year or the three-year returns whether we divide the sample into size quartiles or market-to-book quartiles. For equity issuing firms, performance increases as market-to-book increases. This effect seems strong for firms that issue equity privately where the firms with the highest market-to-book quartile have a positive average excess return over three years and an insignificant negative excess return of $-11.03 \%$ over five years. For the firms issuing equity publicly that are in the highest market-to-book quartile, 
Table 7

Average and median market-to-book adjusted excess returns for three-year and fiveyear periods

The sample includes all the issues of convertible debt and seasoned equity obtained from the Tokyo Stock Exchange new offerings statistics for firms with data available from the PACAP files that are not financial firms and utilities. Excess returns are buy-and-hold returns of issuing firms minus buy-and-hold returns of matching firms of similar size and similar market-to-book.

\begin{tabular}{|c|c|c|c|c|c|c|c|}
\hline & \multicolumn{4}{|c|}{ Convertible issues } & \multicolumn{3}{|c|}{ Equity issues } \\
\hline & \multirow{2}{*}{$\begin{array}{l}\text { Domestic } \\
\text { public } \\
\text { issues }\end{array}$} & \multicolumn{2}{|c|}{ Offshore issues } & \multirow{2}{*}{$\begin{array}{l}\text { Multiple } \\
\text { issues }\end{array}$} & \multirow[t]{2}{*}{ Private } & \multirow[t]{2}{*}{ Public } & \multirow[t]{2}{*}{ Rights } \\
\hline & & Private & Public & & & & \\
\hline \multicolumn{8}{|c|}{ Panel A. Three-year period } \\
\hline Average & -48.38 & -34.86 & -26.66 & -35.26 & -8.52 & -19.48 & -23.22 \\
\hline t-statistic & -8.79 & -4.93 & -1.69 & -2.26 & -0.58 & -3.38 & -1.06 \\
\hline Median & -38.39 & -25.13 & -24.48 & -16.70 & 3.47 & -12.71 & -15.07 \\
\hline \multicolumn{8}{|c|}{ Panel B. Five-year period } \\
\hline Average & -75.26 & -86.62 & -110.9 & -73.14 & -53.63 & -97.61 & -0.15 \\
\hline t-statistic & -7.26 & -6.72 & -3.85 & -3.25 & -2.00 & -7.80 & -0.00 \\
\hline Median & -29.08 & -61.52 & -85.34 & -59.64 & -21.32 & -57.42 & 15.50 \\
\hline
\end{tabular}


the average excess return over three years is an insignificant $-11.45 \%$, but it becomes $72.54 \%$ over five years with a t-statistic of -4.51 . When we look at convertible debt issuing firms, however, there is no monotone relation between market-to-book and performance. We also estimated but do not report here regressions of excess returns on marketto-book and the market value of equity but do not reproduce them here. For domestic public convertible issues and equity issues, both the market value of equity and market-to-book have significant positive coefficients for the five-year excess returns at the 0.05 level. For the three-year excess retums, the market-to-book is positive and significant for firms issuing public convertible debt and the market value of equity is positive and significant for the firms issuing equity publicly. The other coefficients are not significant. However, these regressions have adjusted $\mathrm{R}$-squares of about zero.

\section{Section 5. Conclusion.}

In this paper, we explored the long-term performance of security issuing firms in Japan. The evidence differs from the U.S. and does not provide much support for the underreaction view. We find underperformance for Japanese firms issuing convertible debt or equity even though these firms do not experience significant negative abnormal returns when the issue announcement is made and even though they do not issue following a runup in their stock price relative to the market. In contrast to the U.S., there is no evidence that underperformance is concentrated among the smaller firms. Firms issuing equity privately experience a significant positive abnormal return on the announcement date in excess of $4 \%$, but their post-issue performance is not distinguishable from the performance 
of firms issuing equity publicly. 


\section{References}

Barber, B.M., and J.D. Lyons, 1996a, Detecting long-run abnormal stock returns: The empirical power and specification of test-statistics, unpublished working paper, University of California at Davis, CA.

Barber, B.M., and J.D. Lyons, 1996b, How can long-run abnormal stock returns be both positively and negatively biased?, University of California at Davis, CA.

Brav, Alon, Chris Geczy, and Paul Gompers, 1996, Underperformance of seasoned equity offereings revisited, University of Chicago and Harvard University working paper.

Chan, Louis K.C., Yasushi Hamao, and Josef Lakonishok, 1991, Fundamentals and stock returns in Japan, Journal of Finance 46, 1739-1764.

DeBondt, W.F.M., and R. Thaler, 1995, Does the stock market overreact?, Journal of Finance 40, 793-805.

Fama, Eugene, and Kenneth R. French, 1992, The cross-section of expected stock returns, Journal of Finance 47, 427-466.

Fama, Eugene, and Kenneth French, 1993, Common risk factors in the returns of stocks and bonds, Joumal of Financial Economics 33, 3-55.

Ikenberry, David, Josef Lakonishok, and Theo Vermaelen, 1995, Market underreaction to open market share repurchases, Journal of Financial Economics 39, 181-208.

Jagannathan, R., K. Kubota, and H. Takehara, 1995, The CAPM with human capital:

Evidence from Japan, unpublished working paper, University of Minnesota.

Kahle, Katherine, 1996, Unpublished Ph.d. dissertation, The Ohio State University. 
Kang, Jun-Koo, Yong-Cheol Kim, Kyung-Joo Park, and René M. Stulz, 1995, An analysis of the wealth effects of Japanese offshore dollar-denominated convertible and warrant bond issues, Journal of Financial and Quantitative Analysis 30, 257-270.

Kang, Jun-Koo, and René M. Stulz, 1996, How different is Japanese corporate finance? An investigation of the information content of new security issues, Review of Financial Studies 9, 100-139.

Kato, K., and James Shalheim, 1992, Public and private placements of seasoned equity issues in Japan, unpublished manuscript, The University of Utah.

Kothari, S.P., and Jerold B. Warner, 1996, Measuring long-horizon security price performance, Journal of Financial Economics, forthcoming.

Kubota, K., and H. Takehara, 1995, Common risk factors in Tokyo Stock Exchange Firms, working paper, Musashi University.

Loughran, Tim, and Jay Ritter, 1995, The new issues puzzle, Journal of Finance 50, 23-52.

Myers, Stewart C., and Nicholas Majluf, 1984, Corporate financing and investment decisions when firms have information that investors do not have, Journal of Financial Economics 13, 187-221.

Spiess, Katherine, and John Affleck-Graves, 1995, The long-run performance following seasoned equity issues, Journal of Financial Economics 38, 243-267. 